\title{
Dramatic Response to Ozone Application: Raynaud's Phenomenon
}

\author{
Ozon Uygulamasina Dramatik Yanit: Raynaud Fenomeni \\ Onur Öztürk ${ }^{1,2}$, İsmail Şen², Gülşah Bal ${ }^{1}$, Muhammed Emin Göktepe ${ }^{1}$ \\ ${ }^{1}$ Samsun Education and Research Hospital, Clinic of Family Medicine, Samsun, Turkey \\ ${ }^{2}$ Samsun Education and Research Hospital, Traditional and Complementary Medicine Center, Samsun, Turkey
}

\begin{abstract}
Ozone application is used in medicine with many indications, vascular diseases are one of them. In this case report, the regression of ischemia-related complaints in the finger of a young female patient with Raynaud's Phenomenon after ozone application was mentioned.

Keywords: Ozone, Raynaud's phenomenon
\end{abstract}

\section{Introduction}

Ozone gas which was discovered in 1839 is an inorganic molecule consisting of three oxygen molecules, highly soluble in water and highly oxidant (1). In medical ozone therapy, ozone produced from pure oxygen by a special generator is mixed with the patient's own blood, distilled water or applied to various parts of the body in gaseous form. It is used in medicine with many indications such as dental caries, hypercholesterolemia, ischemia (2).

Raynaud's Phenomenon (RP) is a disorder characterized by cold-induced vasoconstriction in the fingers and toes and progressing with attacks.

Diagnosis is easy when the characteristic skin color change (white, blue-purple or red) that occurs during the occurrence of an attack (3). This case report deals with a patient diagnosed with RP whose complaints was eliminated with ozone application.

\section{Presentation of the case}

A 37-year-old female patient applied to our traditional and complementary medicine center in July 2021 with complaints of coldness, pain, bruising and burning sensation in the left hand that had been present for several months. Her symptoms are triggered by stress
Öz

Ozon uygulamasının birçok endikasyonla tıpta kullanımı söz konusudur, vasküler hastalıklar da bunlardan biridir. $\mathrm{Bu}$ vaka sunumunda Raynaud Fenomeni olan genç kadın hastanın ozon uygulaması sonrası parmağındaki iskemi kaynaklı şikayetlerinin gerilemesinden bahsedilmiştir.

Anahtar kelimeler: Ozon, Raynaud Fenomeni

and cold. The general condition was good; she was conscious, oriented, cooperative, and vital signs were within normal limits. There is an ecchymotic image in the 5th phalanx of the left hand (Figure-1A).

In her medical history, it is learned that cilostazol 100 mg 2x1 medication was administered with the diagnosis of RP in the cardiovascular surgery clinic that she applied with the same complaints; after a month of treatment, there was some regression in her complaints, then she stopped taking the drug and her complaints recurred a few weeks later. The patient, who was hospitalized this time in the same clinic, left the hospital voluntarily, as her complaints continued. In addition, the patient has been smoking 1 pack of cigarettes a day for 20 years. There is no such characteristic in the medical history of her family.

A total of 12 major autohemotherapy (between 20 and 35 gamma) and 4 minor autohemotherapy (30 gamma) sessions of ozone therapy were applied to the patient, 3 days a week, for a month. Intermediate sessions, once a week, were recommended to the patient who was recommended to quit smoking. The patient's pain decreased and her ecchymotic appearance improved (Figure-1B). 


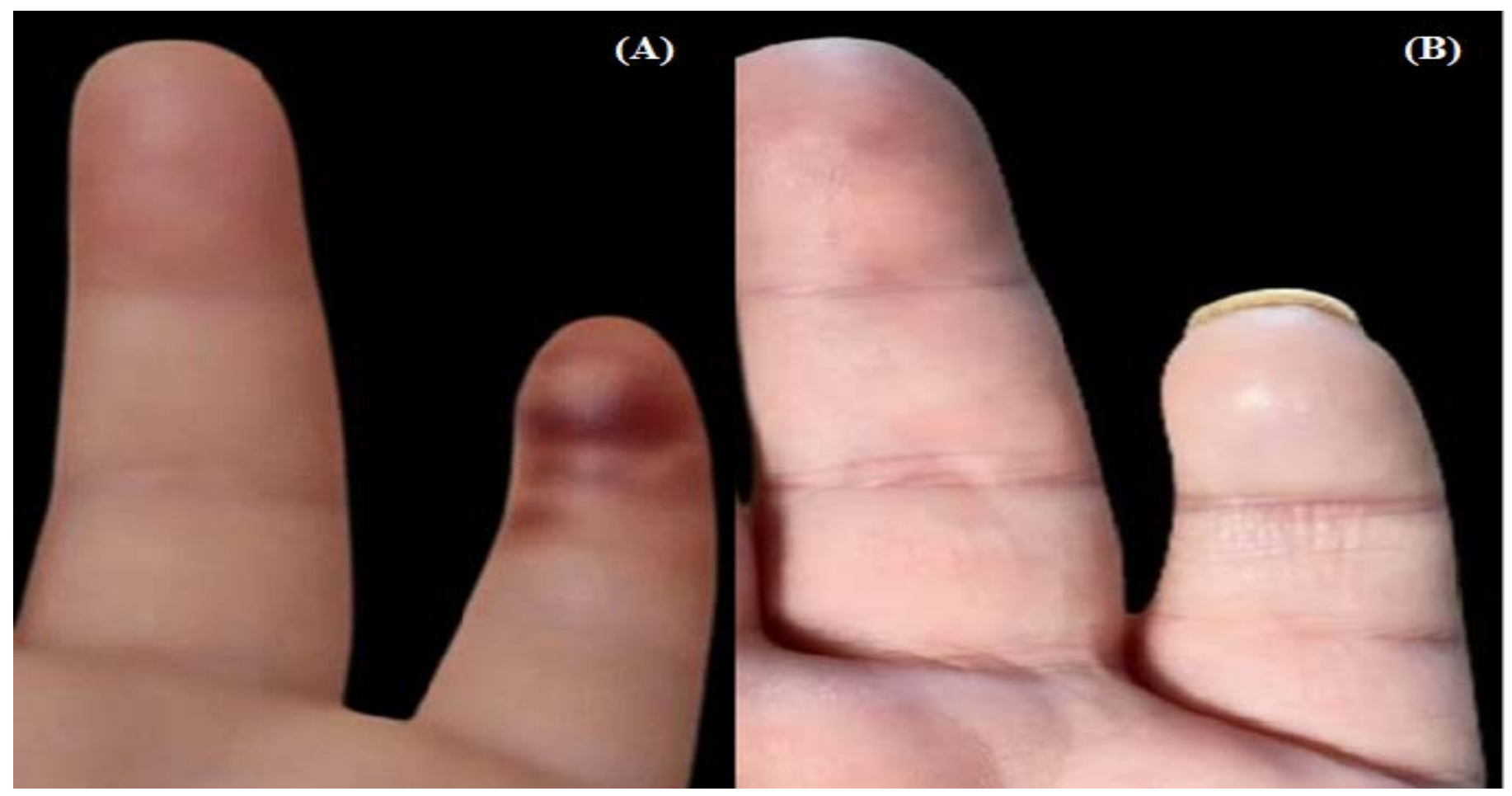

Figure -1. (A) İmage before treatment an ecchymotic 5th phalanx of the left hand. (B) Post treatment

\section{Discussion}

Ozone application has properties such as increasing the amount of oxygen in the blood, increasing blood circulation, activating erythrocyte metabolism, restoring tissue oxygenation and cell function (4). Larini et al. revealed that ozone autohemotherapy can activate antioxidant enzymes and scavenge free radicals (5), and various studies have shown that ozone autohemotherapy can be used to treat vascular diseases $(6,7)$.

$\mathrm{RP}$, which is a vascular problem, may respond well to ozone application as it manifests itself with ischemia in the limbs. Considering the literature on this matter, Haug et al. were among the first physicians who applied ozone to a patient with RP and became successful (8). Cook et al. reported that a combined therapy containing ozone may be beneficial in severe

\section{References}

1- Babucçu O. Ozone Therapy: Myth and Fact. Turk Plast Surg 2011;19 (3): 105-12.

2- Elvis AM, Ekta JS. Ozone therapy: A clinical review. J Nat Sc Biol Med 2011; 2:66-70.

3- Canbaz S, Ege T, Halıcı Ü, et al. Raynaud Phenomenon. T Klin J Cardiovascular Surgery 2004; 5:49-58.

4- Ameli J, Banki A, Khorvash F, et al. Mechanisms of pathophysiology of blood vessels in patients
RP (9). The clinical management of our patient will also contribute to the literature in this regard.

$\mathrm{RP}$ is more common in women in their thirties (3). The demographic datas of our patient are compatible with the literature. RP is clinically classified as primary and secondary. Primary RP is idiopathic and is the most common form of the disease. Secondary RP may accompany diseases such as autoimmune or cancer, or it may be caused by smoking or the use of certain drugs (3). The fact that our patient did not have a known chronic disease may suggest the diagnosis in favor of primary RP, while being a smoker may increase the severity and frequency of his current complaints.

Ozone application provided significant clinical improvement in the patient's symptoms. Thus, it can be applied as a supportive treatment in patients with RP.

with multiple sclerosis treated with ozone therapy: a systematic review. Acta Biomed 2019; 90(3): 213-7. Published 2019 Sep 6. doi:10.23750/abm. v90i3.7265

5- Larini A, Bianchi L, Bocci V. The ozone tolerance: I) enhancement of antioxidant enzymes is ozone dose-dependent in jurkat cells. Free Radical Research 2003; 37(11): 1163-8. 
6- Bocci V, Zanardi I, Travagli V. Ozone: a new therapeutic agent in vascular diseases. American Journal of Cardiovascular drugs 2011; 11(2): 7382.

7- De Monte A, van der Zee H, Bocci V. Major ozonated autohaemotherapy in chronic limb ischemia with ulcerations, Journal of Alternative and Complementary Medicine 2005; 11(2): 363367.
8- Haug KF, Heidelberg, Rilling S, et al. The use of Ozone in Medicine, classical medical ozone textbook, 11 edition, 1987.

9- Cooke ED, Pockley AG, Tucker AT, et al. Treatment of severe Raynaud 's syndrome by injection of autologous blood pretreated by heating, ozonation and exposure to ultraviolet light $(\mathrm{H}-\mathrm{O}-\mathrm{U})$ therapy. Int Angiol 1997, 16:250-4. 